\title{
Terör, Politik ve Askeri Olaylara Borsa İstanbul Turizm Sektörü Yatırımcı Tepkisi
}

\author{
Fatih GÜNAY 1
}

Özet

Çalışmada, terör, politik ve askeri olaylara turizm sektörü pay yatırımcılarının tepkisinin incelenmesi amaçlanmıștır. 2016 yılı sonrasında yaşanan 15 Temmuz darbe girişimi, seçimler, Fırat Kalkanı (2016), Zeytin Dalı (2018) ve Barış̧ Pınarı (2019) sınır ötesi harekâtları incelenen olaylardır. Olay çalışması yöntemiyle on işletmenin günlük verilerinde ortalama getiri modeliyle getiriler hesaplanmıştır. Olay gününde 15 Temmuz'un negatif, Zeytin Dalı'nın pozitif anormal getiriye sebep olduğu bulgulanmıștır. 21 günlük olay penceresinde 15 Temmuz'un negatif, sırasiyla Genel Seçim, IBBB ara seçimi ile Barıș Pınarı'nın en yüksek pozitif kümülatif ortalama anormal getirilere sebep olduğu saptanmıştır. Elde edilen bulgular terör ve güvenlik riskiyle, askeri olaylara turizm sektörü yatırımcı duyarlılığının politik olaylardan yüksek olduğunu göstermektedir.

Anahtar kelimeler: Yatırımcı Tepkisi, 15 Temmuz Darbe Girişimi, Seçimler, Askeri Olaylar, Turizm Sektörü, Olay Çalışması

Jel Kodu: G14, G19, Z33

\section{Reactions of Borsa İstanbul Tourism Sector Investors to Terrorist, Political and Military Events}

\begin{abstract}
It was aimed to investigate the tourism sector investor reactions to terrorist, political and military events. The July 15 coup attempt, three elections, Euphrates Shield (2016), Olive Branch (2018) and Peace Spring (2019) cross-border operations are the examined events experienced after 2016. By the event study method, returns were calculated with the meanadjusted return model in the daily data of ten companies. The findings indicate that the July 15 caused significant negative and the Olive Branch caused significant positive average abnormal return on the event day. In the 21-day event window, it was determined, the July 15 was caused negative, and respectively the Presidential and Deputy General Election, the Istanbul Metropolitan Municipality Interim Election and the Peace Spring were caused the highest positive cumulative average abnormal returns. According to the findings, as expected, it can be said that in tourism sector the investor sensitivity to terrorism and security risks is higher than the political events.
\end{abstract}

Keywords: Investors' Reactions, 15 July Coup Attempt, Elections, Military Events, Tourism Sector, Event Study Jel Codes: G14, G19, Z33

\section{GíRiş}

Reel ekonomiyi doğrudan ve dolaylı olarak etkileyen faktörlerin pay piyasalarında yatırımcı karar ve davranışlarına yansıması beklenir. Risk ve getiriye bağlı olarak alınan yatırımcı kararları işletmelerin firma değerini ve pay getirilerini etkilemektedir. Bir pay senedi veya varlığın anormal getirisi, gözlenen (gerçekleşen) getirinin beklenen getiriden farkıdır. Beklenen getiri, herhangi bir yatırımdan elde edilecek alternatif getiri olarak tanımlanabilmekle birlikte çeşitli yöntemlerle belirlenebilmektedir. Gözlenen getiri ise belirli bir dönemde finansal varlığın değerinde yaşanan değişimdir. Piyasalarda yaşanan beklenmeyen olaylar pay değeri ve getirilerinde etkilidir (Mutan ve Topcu, 2009). Piyasaya yansıyan bir duyurunun, haberin veya ekonomik, politik, afet gibi olayların işletme pay getirilerinde yarattığı etki yatırımcı tepkilerinin göstergesidir.

ATIF ÖNERísí (APA): Günay, Fatih. (2020). Terör, Politik ve Askeri Olaylara Borsa İstanbul Turizm Sektörü Yatırımcı Tepkisi. İzmir İktisat Dergisi. 35(4). 839-856. Doi: 10.24988/ije.202035412

${ }^{1}$ Dr. Öğr. Üyesi, Ağrı İbrahim Çeçen Üniversitesi, Turizm İşletmeciliği ve Otelcilik Yüksekokulu, Merkez / AĞRI, EMAIL: fgunay@agri.edu.tr ORCID: 0000-0003-0892-514X 
Turizm talebi turistin içsel motivasyonları kadar dışsal faktörlerden de etkilenmektedir. İşletmelerin faaliyet performanslarını dolayısıyla finansal performansını etkileyen turizm talebi kırılgan bir yapıya sahiptir. Ekonomik koşullar, güvenlik riski, doğal afet tehlikesi, terör olayları, politik olay ve gelişmeler turizm talebini etkileyen unsurlardandır (Yenişehirlioğlu vd., 2013: 66). Talep esnekliğinin yüksek olduğu turizm sektörü (Zengin, 2010: 122) hızlı gelişme gösteren ve gelişimiyle ekonomik ve sosyal etkiler yaratan bir sektördür (Yıldız, 2011: 69).

Türk turizmi 2014'te ulaştığı yükseliş sonrasında Rusya ile 2015'te yaşanan Uçak Krizi'nin ardından büyük bir ivme kaybetmiștir. Uçak krizinin ardından Türkiye'de öncelikle 2016 Temmuz'unda başarısız bir darbe girișimi, sonrasında 2016 Ağustos aylarında Suriye'nin kuzeyindeki terör oluşumlarına karşı sınır ötesi harekât gibi çeşitli beklenmedik olaylar yaşanmıştır. Ülkeler dış tehdit ve terör eylemlerine karşı sınırlarını ve ülkelerini korumaya yönelik terörist oluşumları bertaraf etme hakkına sahiptir. $\mathrm{Bu}$ kapsamda Türkiye, 2016 yılından itibaren özellikle Suriye'nin kuzeyindeki gelişmelere bağlı olarak DEAȘ ve PKK ile mücadele kapsamında bir dizi operasyon gerçekleştirmiştir. İlk olarak 2014 yılında Niğde'de güvenlik birimlerine silahlı saldırı gerçekleștiren ve yine Türkiye içinde çeşitli terör eylemlerinde bulunan DEAŞ’ın (İçişleri Bakanlığı, 2017: 34) ve uzun yıllardır Türkiye içinde terör eylemleri gerçekleştiren PKK'nin Suriye kolu olan YPG/PYD'nin Suriye'nin kuzeyindeki oluşumlarını bertaraf etme amacı taşıyan üç operasyon gerçekleştirilmiștir. Türkiye tarafindan Suriye'nin kuzeyinde gerçekleştirilen Fırat Kalkanı (2016), Zeytin Dalı (2018) ve Barıș Pınarı (2019) harekâtlarla gerek DEAŞ’ın Suriye'deki oluşumu kırılmış, gerekse Suriye'nin kuzeyinde oluşturulmak istenen terör koridoru yerine güvenli bölge oluşturulması ve Türkiye'ye yönelik tehditlerin azaltılması sağlamıștır (Hürriyet, 2019).
Türkiye, 2017 yılında yapılan halk oylaması ile 2018 yılında Cumhurbaşkanlığı Hükümet Sistemi'ne geçerek yeni sistemde Cumhurbaşkanı ve Milletvekili Genel seçimlerini 2018 yılında gerçekleştirmiştir. Bununla birlikte 2019 yılında Mahalli İdareler genel seçimleri ile İstanbul Büyükşehir Belediye Başkanlık seçimine yapılan itirazlar sonrasında bir ara seçim olmak üzere 2016 sonrasında Türkiye'de üç seçim gerçekleşmiştir (YSK, 2019).

Türkiye'nin bulunduğu bölgede yaşanan iç savaşlar, ülkede meydana gelen terör olayları, siyasi krizler, darbe girişimi ve diğer etkenler gerek ülke gerekse İstanbul turizmini olumsuz etkilemiştir (Bahar ve İstanbullu Dinçer, 2019: 38). Özellikle 2015 'te Rusya ile yaşanan Uçak krizi sonrasında turizm talebinde daralmalar yaşanmıştır (Yaşar ve Yaşar, 2017: 105). Talepte yaşanan daralmaya karşın uçak krizi sonrasında Türk turizm sektöründe faaliyet gösteren işletmelerde olay sonrasında beklenenin aksine pozitif kümülatif anormal getiri gerçekleşmiş olup olay günlerinde herhangi bir anormal getiri gözlenmemiştir (Çelik ve Koç, 2019: 14).

Turizm sektörü risklere duyarlı sektörlerden olmakla birlikte daha önce ifade edildiği gibi turizm talebi politik, askeri, ekonomik, salgın, doğal afet gibi çeşitli olaylardan etkilenmektedir. Talep esnekliğinin yüksek olduğu turizmde pay senedi yatırımcılarının yatırım kararlarında beklenen nakit akışlarına etki edebilecek olayları dikkate alması beklenir. $\mathrm{Bu}$ bilgiler doğrultusunda çalışmada, Türkiye'de 2016 yılı sonrasında yaşanan 15 Temmuz Darbe girişimi, Suriye sınır ötesi harekâtları ve seçimlerin turizm sektörü yatırımcı tepkilerine yansımalarının Olay Çalışması yöntemiyle incelenmesi amaçlanmıştır. Giriş bölümünün ardından 2016 sonrasında Türkiye'de yaşanan temel olaylar araştırmada incelenen olaylar başlığı alt başlıklarında kısaca anlatılmıştır. Literatür taraması çalışmanın ikinci başlığında yer almakla birlikte üçüncü başlık araştırma yöntemi kapsamında araștırmanın amacı ve 
önemi, olay çalışması yöntemi, anormal getiri, veri ve örneklem alt başlıklarından oluşmaktadır. Araştırma bulguları çalışmanın dördüncü bașlığında sunulmuş olup çalışma sonuç bölümü ile tamamlanmıştır.

\section{INCELENEN OLAYLAR}

\subsection{Temmuz Darbe Girişimi}

Türkiye'de, 15 Temmuz 2016 Cuma günü Türk Silahlı Kuvvetleri (TSK) içindeki bir grup Fetullahçı Terör Örgütü (FETÖ) mensubu subay tarafindan saat 22:00'da Genelkurmay Başkanlığı Karargahı'nda başlatılan ve 16 Temmuz Cumartesi günü saat 20:02'de bertaraf edilen darbe girişimi yaşanmıştır (TCCB, 2018: 6).

Silahlı kuvvetlerin kontrol alanı, mesleki profesyonellik ya da koruyucu misyon edinme yaklaşımları ile açıklanması mümkün olmayan 15 Temmuz darbe girişimi (Alkan, 2016: 267) hem milletin iradesini hem de ekonomiyi baskı altına alma girișimidir. 15 Temmuz, siyasi ve ekonomik istikrar ortamını yeniden dizayn etme çabasıyla siyasi otoriteyi hedef almakla birlikte ekonomik alanda etkileri olan başarısız bir darbe girişimidir. Algı operasyonları, kredi derecelendirme kuruluşlarınca not düşürülmesi ve döviz kurunun yükselmesi darbe girişiminin ekonomik maliyetlerindendir (Karagöl, 2016: 50).

\subsection{Seçimler}

Türkiye'de 2017 yılında yapılan anayasa değișikliği referandumuna bağlı olarak anayasa değişikliği sonucunda hükümet sisteminde değişiklik yapılarak cumhurbaşkanlığı hükümet sistemine geçilmiştir (Akçakaya ve Özdemir, 2018: 926-927). Cumhurbaşkanlığı hükümet sistemine geçiş sonrasında yeni hükümet sistemi kapsamında 24 Haziran 2018 tarihinde Cumhurbaşkanı Seçimi ve 27. Dönem Milletvekili Genel Seçimi ile Cumhurbaşkanı ve Milletvekili seçimleri gerçekleştirilmiştir (Turan, 2018: 79; YSK, 2018).

Çalışmada ele alınan dönemde Türkiye'de gerçekleşen bir diğer seçim ise 31 Mart 2019 tarihinde gerçekleştirilen Mahalli İdareler
Genel Seçimleri'dir (YSK, 2019). Diğer yandan 31 Mart'ta gerçekleştirilen yerel seçimde İstanbul Büyükşehir Belediye Başkanlık seçim sonuçlarına itiraza bağlı olarak 23 Haziran 2019 tarihinde İstanbul Büyükşehir Belediye Başkanlık Ara Seçimi yapılmıştır. Türkiye'nin 2018 nüfusunun \%18,4'ü İstanbul'da yaşarken, İstanbul nüfus açısından ilk sırada yer almaktadır (Tüik, 2019). Yine 2018 yılı verilerine göre İstanbul, Türkiye ihracatının \%51'inin yapıldığı, Türkiye'deki mevduatın ise \%43'ünün bulunduğu ildir (Avdagiç, 2019). Birçok yönden Türkiye açısından büyük öneme sahip İstanbul turizm açısından da önemli illerin başındadır.

\subsection{Firat Kalkanı Harekâtı (24 Ağustos 2016)}

Türkiye, sınır komşusu olan Suriye'de 2011 yılında iç karışıklıklarla başlayan Suriye İç Savaşı sonrasında sınırında yaşanan gelişmelere bağlı olarak Suriye'nin kuzeyindeki terör unsur ve oluşumlarına müdahalenin zorunluluk halini alması nedeniyle terörle mücadelede önemli bir aşamaya geçerek "Fırat Kalkanı Harekâtı"nı başlatmıştır (Ulutaş ve Duran, 2017: 21).

Türkiye, başta DEAŞ (Devlet'ül Irak ve'ş Şam) olmak üzere Suriye'de bulunan terör örgütlerinden Türkiye'ye yönelik tehditleri, uluslararası hukuktan doğan meşru müdafaa hakkı kapsamında ve gerektiğinde saldırgan biçimde başka ülkenin topraklarında kendisine sunulan icra etme yetkisine dayanarak tehdidi bertaraf etmeye yönelmiştir. Birleşmiş Milletler Sözleşmesi'nin 51. maddesinin tanıdığı "meşru müdafaa" hakkına dayalı olarak Türkiye, uluslararası kamuoyuna deklare ederek "Fırat Kalkanı Harekâtı"na 24 Ağustos 2016 tarihinde başlamıştır (Yeșiltaş, Seren ve Özçelik, 2017: 9).

Fırat Kalkanı Harekâtı ile Türkiye, sınırın tüm terör unsurlarından temizlenerek sinır güvenliğinin tesisi, DEAŞ’ı sınır hattından temizleyerek geriye püskürtmek böylelikle örgütün operasyonel ağırlı merkezinin dağıtılarak özellikle sınır illerine yönelik saldırıların önlenmesi, PKK'nın Suriye'deki kolu YPG'nin Suriye'nin kuzeyinde doğu-batı 
hattını kontrol altına almasını engelleyerek koridor oluşturmasına mani olmak ve terörden temizlenen alanlarda fiili güvenli bölge oluşturarak mültecilerin bu bölgelere dönmelerini sağlamak öncelikli hedeflerine ulaşmayı amaçlamıştır (Ulutaş ve Duran, 2017: 21; Yeşiltaş vd., 2017: 10). 24 Ağustos 2016'da başladığı ilan edilen operasyon DEAȘ'ın sınır hattından temizlenmesi ve Türkiye sınırından Suriye'nin $40 \mathrm{~km}$ derinliğine kadar terör örgütlerinden temizlenmesiyle 29 Mart 2017 tarihinde tamamlanmıştır (Milli Güvenlik Kurulu, 2017; Ulutaş ve Duran, 2017: 25). Ulaşılan bu hedeflerin yanı sıra harekât ile Türkiye'nin güneyinin güvenlik altına alınması ve DEAŞ'ın kritik noktalarını ele geçiren PYD/YPG'nin Afrin ile bağlantı kurması fiilen engellenmiştir (Yeltin, 2018: 212).

\subsection{Zeytin Dalı Harekâtı (20 Ocak 2018)}

Türk Silahlı Kuvvetleri (2018), Türkiye sınırlarında ve bölgede güvenlik ve istikrarı sağlamak amacıyla, Suriye'nin kuzeybatısında Afrin bölgesinde, PKK/KCK/PYD-YPG ve DEAŞ’a bağlı terör gruplarını etkisiz hale getirmek ve bölge halkını terör baskı ve zulmünden kurtarmak üzere 20 Ocak 2018 saat 17:00'dan itibaren Zeytin Dalı Harekâtı'nın başlatıldığını duyurmuştur. Suriye'nin kuzeyinde Afrin bölgesine yönelik 20 Ocak 2018 (Cumartesi) tarihinde YPG ve PYD'ye yönelik başlatılan Zeytin Dalı Harekâtı Türkiye'nin uluslararası hukuktan kaynaklanan hakları (BM 51. maddesinde yer alan Meşru Müdafaa Hakkı) çerçevesinde, Suriye'nin toprak bütünlüğüne saygılı olarak icra edilmiştir (Kibaroğlu, 2018: 12-16). Afrin şehir merkezinin teröristlerden arındırılmasıyla başlangıcından 58 gün sonra 18 Mart 2018 tarihinde operasyon tamamlanmıştır (Cnn Türk, 2019).

\subsection{Barış Pınarı Harekâtı (9 Ekim 2019)}

Milli Savunma Bakanlığı tarafından yapılan açıklamayla hudutların güvenliğini sağlamak, sinırların güneyinde terör koridoru oluşturulmasını engellemek, DEAŞ ve PKK/KCK/PYD-YPG bașta olmak üzere milli güvenliğe tehdit oluşturan terör örgütleri ve teröristleri etkisiz hale getirmek, yerinden edilen Suriyelilerin evlerine ve kendi topraklarına dönüşleri için uygun şartları sağlamak amacıyla Barış Pınarı Harekâtı 9 Ekim 2019 saat 16.00 'da başlatıldığı belirtilmiştir (Milli Savunma Bakanlığı, 2019a).

Harekâtın başlama ve yürütülme sürecinde uluslararası anlamda Türkiye'nin temel muhatabı ABD olmuştur. ABD ile varılan mutabakatla birlikte ABD'nin harekât kapsamındaki bölgelerden askeri unsurlarını çekmesi önem taşımaktadır. Ayrıca Türkiye tarafından BMGK üye ülkeleri, NATO ve BM genel sekreterlerinin yanı sıra İran'a da gerekli diplomatik bildirimler yapılmıştır. Uluslararası anlamda olumlu ve/veya olumsuz çeşitli tepkiler gözlenmiş olmakla birlikte (Kurt, 2019) operasyonun gerçekleştirildiği Barış Pınarı Harekâtı bölgesinde 15.12.2019 itibariyle hayat normale dönmektedir (Milli Savunma Bakanlığı, 2019b).

\section{LITERATÜR TARAMASI}

Seçimler, askeri olaylar ve darbe girişiminin Türkiye'de turizm sektörü işletmeleri anormal getirilerine etkilerinin incelendiği çalışmanın bu bölümünde; çeşitli olay, duyuru ve haberlerin olay çalışması yöntemiyle pay getirilerine etkilerini inceleyen çalışmalar özetlenmektedir.

Thorbacke (1997) yaptığı çalışmada para politikası şoklarına pay getirileri tepkisini tespit etmeyi amaçladığı çalışmasında, ABD merkez bankasının genişlemeci para politikasının olay sonrasında pay getirilerini arttırdığı gözlenmiștir. Borde, Byrd ve Atkinson (1999) ise temettü artış duyurularının ağırlama endüstrisi pay fiyatlarına tepkisini standart olay çalışması yöntemiyle incelemişlerdir. Çalışma sonuçları, temettü artışlarının piyasa tarafından olumlu karşılandığını ortaya koymaktadır. Temettü artış büyüklüğüyle piyasa tepkisinin pozitif ilişkili olduğu saptanmış olup elde edilen sonuçlar temettü politikasındaki değişikliklerin işletmenin gelecek finansal durumu hakkında işaret olarak algılandığı için yöneticilerin temettü politikasındaki etkileri dikkatli bir șekilde göz 
önüne alması gerektiğini göstermektedir. Sheel ve Zhong (2005) olay çalışması yöntemiyle ağırlama işletmelerinde nakit temettü duyurularının anormal getirilerine etkilerini ABD'de 1994-2002 döneminde incelemeyi amaçlamışlardır. Çalışmada elde edilen bulgular nakit temettülerin konaklama ve yiyecek-içecek hizmetleri sektörlerinin her ikisinde de yatırımcılar tarafından olumlu algılandığını göstermektedir. Sonuçlar anormal getirilerin iki sektörde farklı olduğunu ve konaklama işletmelerinde daha ihtiyatlı temettü politikasına ihtiyaç olduğunu ortaya koymaktadır.

Berman, Brooks ve Davidson (2000) yaptıkları çalışmada $\quad 2000 \quad$ olimpiyatlarının gerçekleştirileceği ev sahibi ülke Avustralya'da borsa tepkisini incelemişlerdir. Çalışmada borsa üzerinde genel bir etki saptanmamıșken, olimpiyat duyurusunun inşaat ve yapı ile ilgili bazı sektörlerde anlamlı pozitif etki yarattığı tespit edilmiştir. Veraros, Kasimati ve Dawson (2004) 2004 olimpiyatlarına aday ülkelerden Yunanistan ve İtalya borsalarına olimpiyat duyurularının etkilerini olay çalışması yöntemiyle incelemişlerdir. Çalışmada olimpiyatlarda ev sahipliği hakkı kazandığı duyurulan Atina borsası ve özellikle altyapı ile ilişkili endüstrilerde pozitif etki saptanırken, olimpiyatları gerçekleștirme hakkını kaybeden Milan borsasında ise anlaml bir etki saptanmamıștır.

Nicolau (2002) olay çalışması ve regresyon analizi yöntemiyle İspanya menkul kıymetler borsasında işlem gören otel zincirlerinde yeni bir otel açlışının etkilerini analiz etmiştir. Çalışmada yeni otel açılış haberlerinin yüksek düzeyde pozitif etkili olduğu ayrıca açılacak otelin coğrafi bölgesinin en önemli faktör olduğu tespit edilmiştir. Dogru ve SirakayaTurk (2016) Enerji ve Çevresel Tasarımda Liderlik belgeli otel açılış duyurularına pay fiyatları tepkilerini olay çalışması yöntemiyle ölçmeyi amaçlamışlardır. 2009-2013 döneminde 15 otel açılışının incelendiği çalışmada, duyuru sonrasında anlamlı negatif anormal getiri tespit edilmiștir. Bu bulgu pay senedi yatırımcılarının sürdürülebilir yatırımları kısa dönemde değer düşürücü olarak algıladığına işaret etmektedir.

Chen, Jang ve Kim (2007) 2003 SARS salgınının Tayvan otel pay fiyat hareketlerine etkilerini olay çalışması yöntemiyle ölçmüşlerdir. Çalışmada salgının Tayvan otel paylarında anlamlı negatif kümülatif ortalama anormal getirilere neden olduğu tespit edilmiştir.

Kim, Kim ve Hancer (2009) ağırlama işletmelerinde bilgi teknolojileri yatırım duyurularının pay fiyatlarına etkisini olay çalışması yöntemiyle incelemişlerdir. Çalışmada bilgi teknolojileri yatırımları ile finansal performansın pozitif ilişkili olduğu yönünde önemli bulgulara ulaşılmıştır. Bununla birlikte anormal getiri ile kümülatif anormal getiri trendinin üç günlük olay penceresinde istikrarlı artış sergilediği gözlenmiştir. Szutowski ve Bednarska (2014) Varşova borsasında işlem gören turizm işletmeleri örneğinde inovasyon duyurularına yatırımcı tepkisini olay çalışması yöntemiyle tespit etmeyi amaçlamışlardır. Çalışma, inovasyonun yatırımcıların turizm işletmeleri değerlemelerini pozitif etkilediğini göstermektedir. Ayrıca yatırımcıların en fazla pazarlama, dağıtım ve dış işbirliklerine yönelik inovasyona tepki gösterdiğini ve en yüksek tepkinin inovasyon duyurusundan sonraki 5 gün içinde gerçekleştiği saptanmıştır. Qin vd. (2017) konaklama ve havayolu işletmelerinde mobil uygulamaların pay getirilerine etkilerini olay çalışması yöntemiyle incelemişlerdir. Elde edilen bulgular hissedar getirilerinin mobil uygulamalardan pozitif etkilendiğini ve mobil uygulamalara uyum hızının pay değerine anlamlı bir etkisinin olmadığını ortaya koymaktadır.

Mutan ve Topcu (2009) yaptıkları araştırmada 2 Ocak 1990-22 Mayıs 2009 tarihleri arasında meydana gelen ekonomik, politik, çevresel, askeri ve terör kaynaklı 10 adet beklenmedik olayın Türkiye hisse senedi piyasasına etkilerini IMKB 100 (BIST100) endeksi bağlamında ölçmeyi amaçlamışlardır. Olay çalışması yöntemiyle günlük endeks 
getirilerinin kullanıldığı araştırmada elde edilen bulgular incelendiğinde en yüksek negatif anormal getirinin 19 Şubat 2001 ekonomik krizinde gerçekleştiği, 6 günlük birikimli olağandışı getirilerde en yüksek getirinin ise 02 Ağustos 1990 Irak'ın Kuveyt'i işgalinde olduğu tespit edilmiştir. İncelenen olaylardan endekste toparlanmanın en uzun sürdüğü olağandıșı olayın ise 15 Eylül 2008 Lehman Brothers'ın iflası olduğu saptanmıştır. Chang ve Zeng (2011) tarafindan ABD'de yapılan çalışmada terör olaylarının turizm işletmeleri pay getirilerini negatif etkilemesi beklentisine karşın, terörün ülkeye yönelik tehdit olarak alglanarak ulus ruhuna ve yatırımcı duyarlılıklarına etkisi nedeniyle terör olaylarının pozitif anormal getirilere sebep olduğu saptanmıştır.

Madanoglu, Olsen ve Kwansa (2010) yaptıkları çalışmada Endonezya, Türkiye ve İspanya'da gerçekleşen bombalı terör saldırılarının bu ülkelerde payları borsada işlem gören ağırlama ve turizm işletmelerinin piyasa değerlerine etkisini incelemeyi amaçlamışlardır. Çalışmada, piyasaların bu terör eylemlerine negatif tepki gösterdiği ve Türkiye'deki piyasa tepkisinin İspanya'daki piyasa tepkisinden daha hafif olduğu bulgusuna ulaşılmıştır.

Nezerwe (2013) Mısır'da başkanlık seçimleriyle pay getirileri ilişkisini tespit etmeyi amaçladığı çalışmada günlük getiriler en küçük kareler regresyon yöntemiyle analiz edilmiştir. Her olay penceresinin başkanlık seçimleri çevresinde 90 günü kapsayan çalışmada elde edilen sonuçlar Mısır'da pay getirilerinde seçimlerin pozitif etkili olduğu tespit edilmiştir.

Kaya, Keskin Köylü ve Günay (2017) Türkiye'de 2016 yılında 15 Temmuz darbe girişiminin BIST30 ve BIST100 endeksleri üzerindeki etkisini olay çalışması yöntemiyle analiz etmişlerdir. Çalışma sonuçlarına göre BIST30 ve BIST100 endekslerinin darbe girişimi öncesi bazı yatırımcılarca Borsa İstanbul'da pozisyon aldıkları kanısına varılmıştır. Elde edilen sonuçlar bazılarının darbe girişiminin uluslararası platformda olumlu karşılanacağı beklentisi ile yatırım yaptıkları yönünde bir izlenim bırakmıştır.

Şahin, Konak ve Karaca (2017) 24 Kasım 2015 tarihinde Türkiye ile Rusya arasında yaşanan Uçak Krizi olayına Borsa İstanbul Gıda, İçecek ve Turizm Endekslerinde yer alan işletmelerin hisse senetlerinin tepkilerini tespit etmeyi amaçlamışlardır. Olay çalışması yöntemiyle yapılan araştırmadan elde edilen bulgulara göre BIST Gıda, İçecek Endeksi'ne kote işletmelerin olaya tepkilerinin negatif olduğu, BIST Turizm Endeksi'ne kote işletmelerin olay sonrası dönemde pozitif anormal getiri değerlerine sahip olduğu saptanmıştır. Ayrıca Kümülatif Ortalama Anormal Getiri değerlerinin çoğunun negatif olduğu bulgusuna ulaşılmıştır. Çelik ve Koç (2019) yine 24 Kasım 2015 Uçak Krizine Borsa İstanbul'daki Turizm ve Enerji işletme hisselerinin tepkilerini olay çalışması ile incelemeyi amaçlamışlardır. 7 adet Turizm 7 adet Enerji işletmesinin hisse getirilerinde meydana gelen değişimlerin incelendiği çalışmada enerji sektöründe incelenen tüm gün aralıklarında istatistiki anlamlı bir sonuç tespit edilememiştir. Elde edilen bulgulara göre $(-5,+5)$ gün aralığında BIST Turizm sektörü işletmelerinin olay sonrası pozitif kümülatif anormal getiri (CAR) sergilediği ancak baz olay öncesi ve sonrası diğer gün aralıklarında herhangi bir anormal getirinin olmadığı saptanmıştır.

Demir ve Ersan (2018) 2002-2013 döneminde ekonomik politika belirsizliğinin Türkiye'de payları borsada işlem gören turizm işletmeleri pay fiyatlarına etkilerini incelemişlerdir. Çalışmada turizm endeks getirilerinde Avrupa ve Türkiye ekonomik güven endekslerinin anlamlı negatif etkileri olduğu bulgulanmıştır. Bulgular Türk turizm işletmeleri getirilerinin ulusal ve uluslararası ekonomik belirsizliklere bağlı olduğunu göstermektedir.

Yapa ve Akbulut (2018) yaptıkları çalışmada Türkiye'de Cumhurbaşkanlığı ve genel seçimin (24 Haziran 2018) erkene alınmasının ilanı (18 Nisan 2018) ve seçim sürecinin dolar TL paritesinin getirisi ve BIST100 endeksi getirisi üzerine etkilerini olay çalışması yöntemiyle 
incelemiştir. Olay tarihleri dikkate alınarak 15 gün, 5 gün ve olay günlerinin değerlendirildiği çalışmada dolar hareketliliğinin BIST100 endeksine kıyasla erken seçim ilanı ve seçim süreçlerinde daha yakın benzerlik gösterdiği saptanmıştır. Erken seçim ilanı dikkate alındığında, ilan öncesinde dolar getirisi ve BIST100 endeksi getirilerinin negatif olduğu, ilan sonrasinda ise dolar getirisinin pozitif eğimli artış gösterdiği saptanmıştır. Seçim öncesi ve sonrası değerlendirildiğinde ise, seçimden 5 gün önce TL dolara karşı değer kazanırken, Borsa İstanbul 100'de de artış gözlemlenmiştir. $\mathrm{Bu}$ durum seçim sonuçlandıktan sonraki 5 günde de bu şekilde gerçekleşmiş ve seçimin bir gün sonrası dikkate alındığında hem dolar getirisi hem de BIST100 endeks getirisinin pozitif olduğu gözlenmiștir.

Çömlekçi ve Şahin (2019) 2015-2017 yılları arasında Türkiye'de yaşanan askeri, siyasi ve ekonomik altı olayın Borsa İstanbul 100 endeksinde yer alan işletmelerin pay getirilerine etkisini olay çalışması yöntemiyle incelemişlerdir. Fırat Kalkanı Harekâtının olay gününde, Anayasa referandumunun $t+1$ gününde ve Varlık Fonu'nun kurulmasının $t+9$ gününde aşırı getiriye sebep olduğu saptanmiştır. İncelenen olaylarda $(-1,+1)$ olay penceresinde tüm olaylarda piyasaların yarı güçlü formda etkin olduğu yönünde işaretler gözlenmiştir. Diğer olay pencerelerinde olaylara bağlı olarak farklılık göstermekle birlikte genel olarak Borsa İstanbul 100 endeksinin yarı güçlü formda etkin olmadığ bulgusuna ulaşılmıştır.

\section{YÖNTEM}

Çalışmada terör, politik ve askeri çeşitli olayların payları borsada işlem gören turizm sektörü işletmeleri piyasa performansına ve getirisine etkisinin olay çalışması yöntemiyle incelenerek yatırımcı tepkisinin tespit edilmesi amaçlanmıştır. Turizm sektörü ekonomik gelişmeler kadar, politik ve ülke riskine etki edebilecek gelişmelere bağlı olarak faaliyet riski yüksek sektörlerin başındadır. Turizm sektöründe faaliyet gösteren işletmelerin faaliyet riskine yarattığı etkiye bağlı olarak gelişmeler karşısında yatırımcı kararları dolayısıyla pay getirilerinin etkilenmesi beklenmektedir. Çalışma; terör, politik ve askeri olayların turizm sektörü pay getirileri ve yatırımcl tepkilerini tespit etmesi nedeniyle önem taşımaktadır.

Tablo 1: Borsa İstanbul Lokanta ve Oteller sektör sınıfında yer alan işletmeler.

\begin{tabular}{|c|c|}
\hline Borsa Kodu & Şirket Unvanı \\
\hline AYCES & Altın Yunus Çeşme Turistik Tesisler A.Ș. \\
\hline AVTUR & Avrasya Petrol ve Turistik Tesisler Yatırımlar A.Ş. \\
\hline ETILR & Etiler Gıda ve Ticari Yatırımlar Sanayi ve Ticaret A.Ș. \\
\hline KSTUR* & Kuștur Kușadası Turizm Endüstri A.Ș. \\
\hline MAALT & Marmaris Altınyunus Turistik Tesisler A.Ş. \\
\hline MARTI & Martı Otel İșletmeleri A.Ș. \\
\hline MERIT* $^{*}$ & Merit Turizm Yatırım ve İșletme A.Ș. \\
\hline METUR & Metemtur Otelcilik ve Turizm İșletmeleri A.Ș. \\
\hline PKENT & Petrokent Turizm A.Ș. \\
\hline TEKTU & Tek-Art İnșaat Ticaret Turizm Sanayi ve Yatırımlar A.Ș. \\
\hline ULAS & Ulașlar Turizm Yatırımları ve Dayanıklı Tüketim Malları Ticaret Pazarlama A.Ș. \\
\hline UTPYA & Utopya Turizm İnșaat İșletmecilik Ticaret A.Ș. \\
\hline
\end{tabular}

Kaynak: Kamuyu Aydınlatma Platformu, 2019.

Günlük verilerin kullanımı çeşitli sorunlar taşımakla birlikte (Brown ve Warner, 1985: 46), olay çalışmalarında sıklıkla tercih edilmektedir. Özellikle beklenmeyen olayların getirilere olan etkilerinin tespitinde günlük veriler kullanılmaktadır. $\mathrm{Bu}$ çalışmada da günlük logaritmik getiriler kullanılmıştır. Çalışma örneklemi Borsa İstanbul'da lokanta 
ve oteller sektör sınıfında verileri analize uygun olan işletmelerdir. 12 Aralık 2019 itibariyle lokanta ve oteller sektör sınıfinda on iki işletme yer almaktadır. İki işletmenin incelenen tüm olaylarda sağlıklı pay değerleri yer almadığı ve belirli günlerde işlem görmediği için örnekleme dâhil edilmemiştir.

İşletmelerin pay getirilerinin hesaplanmasında kullanılan pay senetleri kapanış değerleri 12.12.2019 tarihinde Investing.com finans piyasaları platformundan (Investing.com, 2019) elde edilmiştir. Çalışma kapsamında incelenen olayların duyuru bilgileri, çalışmada kabul edilen olay günleri $(\mathrm{t}=0)$ ve olay penceresi $(-10,+10)$ Tablo 2 'de gösterilmektedir.

Tablo 1: Olaylar, Tarihleri ve Olay Günleri ve Olay Pencereleri

\begin{tabular}{|l|c|c|c|}
\hline Olay & $\begin{array}{c}\text { Olay Tarihi ve } \\
\text { Bilgileri }\end{array}$ & $\begin{array}{c}\text { Olay Günü } \\
\mathbf{( t = 0 )}\end{array}$ & $\begin{array}{c}\text { Olay Penceresi } \\
\mathbf{( - 1 0 , + 1 0 )}\end{array}$ \\
\hline 15 Temmuz Darbe Girişimi & $\begin{array}{c}15.07 .2016 \\
\text { (Cumartesi) 22:05 }\end{array}$ & 18.07 .2016 & $\begin{array}{c}29.06 .2016- \\
01.08 .2016\end{array}$ \\
\hline Frrat Kalkanı Harekâtı & $\begin{array}{c}24.08 .2016 \\
\text { (Çarşamba) 04:00 }\end{array}$ & 24.08 .2016 & $\begin{array}{c}10.08 .2016- \\
08.09 .2016\end{array}$ \\
\hline Zeytin Dalı Harekâtı & $\begin{array}{c}20.01 .2018 \\
\text { (Cumartesi) 17:00 }\end{array}$ & 22.01 .2018 & $\begin{array}{c}08.01 .2018- \\
05.02 .2018\end{array}$ \\
\hline Barış Pınarı Harekâtı & $\begin{array}{c}09.10 .2019 \\
\text { (Çarşamba) 16:00 }\end{array}$ & 09.10 .2019 & $\begin{array}{c}25.09 .2019- \\
23.10 .2019\end{array}$ \\
\hline Cumhurbaşkanı Seçimi ve 27. Dönem Milletvekili & $\begin{array}{c}24.06 .2018 \\
\text { (Pazar) }\end{array}$ & 22.06 .2018 & $\begin{array}{c}07.06 .2018- \\
06.07 .2018\end{array}$ \\
\hline Genel Seçimi & $\begin{array}{c}31.03 .2019 \\
\text { (Pazar) }\end{array}$ & 29.03 .2019 & $\begin{array}{c}15.03 .2019- \\
12.04 .2019\end{array}$ \\
\hline Mahalli İdareler Genel Seçimi & $\begin{array}{c}23.06 .2019 \\
\text { (Pazar) }\end{array}$ & 21.06 .2019 & $\begin{array}{c}07.06 .2019- \\
05.07 .2019\end{array}$ \\
\hline İstanbul Büyükşehir Belediye Başkanlık Ara & & & \\
Seçimi & &
\end{tabular}

Olay tarihi, duyuru bilgisi, duyuru bilgisine dayalı olarak belirlenen olay günü, olay gününün 10 gün öncesi ve sonrasını kapsayan olay penceresi bilgileri Tablo 2'de yer almaktadır. Tablo incelendiğinde olay günü $(\mathrm{t}=0)$ borsanın kapalı olduğu güne denk gelen seçim dışı olaylar için olay günü sonrası ilk gün, seçimlerde ise seçim öncesi son iş günü olay günü $(\mathrm{t}=0)$ olarak belirlenmiștir.

\subsection{Olay çalışması}

Birçok alan ve konuda uygulanan Olay Çalışması, herhangi bir olay veya duyurunun piyasaya ve pay fiyatlarına yansımalarını tespit etmede kullanışlı bir yöntemdir (Çelik ve Koç, 2019: 5). Finans araştırmalarında sıklıkla kullanılan yöntemin amacı; kazanç, birleşme duyuruları, hisse bölünmeleri gibi belirli olaylarda hissedarların getirilerinde anormal getiri elde edip etmediklerinin belirlenmesidir (Peterson, 1989: 36). Anormal getiri olay çalışmalarının çıkış noktasını oluşturmakla birlikte olay çalışmaları belirli bir olayın işletme değeri üzerindeki etkisine odaklanmaktadır (Mutan ve Topcu, 2009: 5). Bir olayın etkilerinin pay fiyatlarına hemen yansıması beklendiğinde kullanışlı olan ve yaygın kullanılan olay çalışması yöntemi (Elbir ve Kandır, 2017: 18) istisnalar olmakla birlikte, etkin piyasa hipotezinde yarı güçlü form piyasa etkinliğine kanıtlar sunmaktadır (Ross, Westerfield ve Jaffe, 2002: 353). Diğer ifadeyle olay çalışması piyasaya ulaşan bilginin belirli bir zamanda fiyatlara olan etkisini inceleyen yöntemdir (Ross vd., 2002: 922). Bunun yanı sıra piyasaları etkileyen ekonomik, siyasi, askeri, kültürel, afet gibi çeşitli olayların pay getirilerinde meydana getirdiği değişimin incelenmesinde yine olay çalışması yöntemi kullanılmaktadır (Çömlekçi ve Şahin, 2019: 48).

Çeşitli uygulama yöntemleri bulunan olay çalışması temelde belirli unsurlara sahiptir 
(Peterson, 1989: 36). Olay çalıșması yönteminde periyotlar "hesaplama dönemi", "olay penceresi" ve "olay sonrası dönem" olarak ele alınmaktadır (Şahin, Konak ve Karaca, 2017: 478). Parametre tahmini için olaydan önceki bir süreyi kullanan bir olay çalışmasının zaman çizelgesi Şekil 1'deki gibidir (Peterson, 1989: 38; MacKinlay, 1997: 20; Şahin vd., 2017: 478).

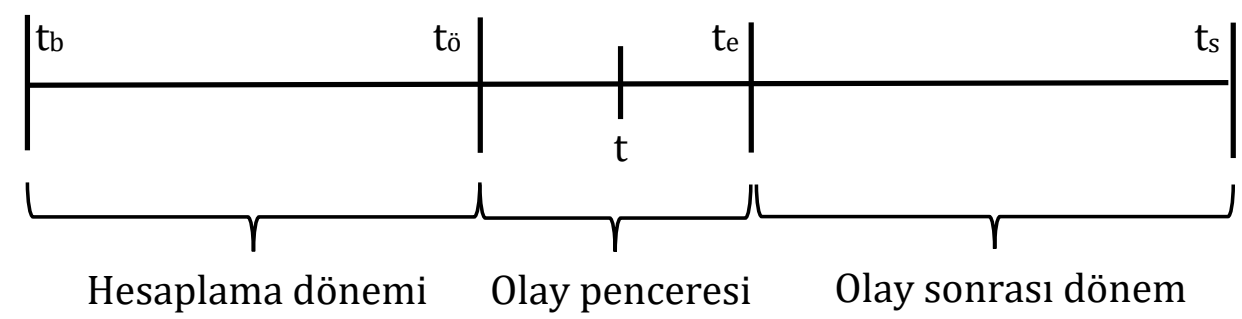

Şekil 1: Olay çalışmasında zaman çizelgesi

Zaman çizelgesinde;

$t_{b}=$ hesaplama döneminin ilk günü,

$t_{o ̈}=$ anormal getirinin hesaplandığ 1 ilk gün (olay penceresinin ilk günü),

$\mathrm{t}=$ olay günü,

$t_{\mathrm{e}}=$ olay penceresinin son günü,

$\mathrm{t}_{\mathrm{s}}=$ anormal getirinin incelendiği olay sonrası dönemin son gününü ifade etmektedir.

Etkisi incelenen olay belirli bir tarihte gerçekleşse veya duyurulsa da, olay penceresi uzunluğunun birden büyük alınması (örn. $3,+3)$ gerekir. $\mathrm{Bu}$, analizde olay günü çevresinde anormal getirilerin kullanımını kolaylaştırır (MacKinlay, 1997: 19). Her bir olayın 10 gün öncesi ve 10 gün sonrasını gösteren $(-10,+10)$ olay penceresinin baz alındığı bu çalışmada hesaplama dönemi uzunluğu 229 gün $(-239,-11)$ olarak belirlenmiștir. Olay tarihini kapsayan olay penceresinin 21 gün ve hesaplama dönem uzunluğunun 229 olarak belirlendiği çalışmada incelenen dönem uzunluğu 250 gündür.

\subsection{Anormal getiri}

Aşırı ya da anormal getiri, kabul edilen risk düzeyinde elde edilecek getiri oranından daha yüksek olan getiri oranıdır (Çıtak ve Ersoy, 2016: 49). Diğer ifadeyle belirli bir model ile olması gereken (beklenen) getiri ile gözlenen getiri arasındaki farktır (Peterson, 1989: 36). İşletme pay senetlerinde beklenen getirinin hesaplanmasında ortalama getiri modeli, piyasa modeli, endeks modeli, sermaye varlıkları fiyatlama modeli (SVFM-CAPM), Fama-MacBeth modeli, kontrol portföy modeli gibi çeşitli modeller bulunmaktadır (Brown ve Warner, 1985: 6-7; Armitage, 1995: 31; MacKinlay, 1997: 17-19). Anormal getirinin gerçek derecesi bilinmediğinden hangi modelin daha iyi olduğunu söylemek imkânsızdır (Armitage, 1995: 31). Kolay bir model olmakla birlikte ortalama getiri modelinde ulaşılan getirilerin, sistematik riski dikkate alan diğer modellerde ulaşılan sonuçlara yakın olduğu saptanmıştır (Brown ve Warner, 1980: 224; MacKinlay, 1997: 17). Anormal getiri hesaplamada, pay senedinin bir hesaplama dönemi boyunca ya da test dönemi çevresinde elde edilen ortalama getiri kadar kazandığını varsayan ortalama getiri modelinin tercih edildiği bu çalışmada anormal getiri Formül 1'de gösterildiği şekilde hesaplanmaktadır (Brown ve Warner, 1985: 6; Armitage, 1995: 27; Mutan ve Topcu, 2009: 6).

$A R_{i, t}=R_{i, t}-\bar{R}_{i}$

Formül 1 'de yer alan $A R_{i, t} i$ işletmesinin $t$ günündeki anormal (aşırı) getirisini, $R_{i, t} i$ işletmesinin $t$ günündeki getirisini, $\overline{\mathrm{R}}_{\mathrm{i}} \mathrm{i}$ pay senedinin hesaplama dönemi ortalama getirisini ifade etmektedir.

Getiri hesaplamada aritmetik ve geometrik getirilerin hesaplanması mümkün olmakla birlikte bir pay senedine ait aritmetik getiri 
Formül 2'de, geometrik getiri ise Formül 3'te gösterildiği gibi hesaplanmaktadır (Çıtak ve Ersoy, 2016: 50).

$R_{t}=\frac{P_{t}-P_{t-1}}{P_{t-1}}=\frac{P_{t}}{P_{t-1}}-1$

$G R_{t}=\ln \left(\frac{P_{t}}{P_{t-1}}\right)$

Formüllerde yer alan $\mathrm{P}_{\mathrm{t}}$ pay senedinin $\mathrm{t}$ zamanındaki kapanış fiyatı, $P_{t-1}$ pay senedinin t-1 zamanındaki kapanış fiyatıdır. Geometrik getiri hesaplamada pay senedi kapanış fiyatındaki değişimin doğal logaritması alınmaktadır. Geometrik getiriler daha anlamlı sonuçlar ortaya koyacağından (Çıtak ve Ersoy, 2016: 50) genellikle tercih edilen hesaplama yöntemidir. Getirisi hesaplanan varlığın çalışma zaman periyodu günlük olduğunda günlük kapanış, haftalık veya aylık olduğunda haftalık veya aylık kapanış fiyatları alınarak getiri hesaplanmaktadır.

Ortalama getiri modeline göre aşırı getiri hesaplamada i pay senedi beklenen getirisini ifade eden ortalama getiri $\left(\overline{\mathrm{R}}_{\mathrm{i}}\right)$ Formül 4'te gösterildiği şekilde hesaplanmaktadır (Chen ve Siems, 2007: 86).

$\bar{R}_{i}=\frac{1}{229} \sum_{t=-239}^{-11} R_{i t}$

Formül 4'te olay günü $0(\mathrm{t}=0)$ olarak kabul edildiğinde, $\overline{\mathrm{R}}_{\mathrm{i}}$ i pay senedinin olay penceresi öncesi hesaplama dönemi $(-239,-11) 229$ günlük getiri ortalamasıdır.

İşletmelere ait anormal getiriler elde edildikten sonra incelenen işletmelerin ortalama anormal getirileri tespit edilmiştir. Ortalama anormal getiriler incelenen işletmelerin anormal getirileri toplamının işletme sayısına bölünmesiyle elde edilmekle birlikte Formül 5'te gösterildiği şekilde hesaplanmaktadır (Brown ve Warner, 1985: 7; Kaderli, 2007: 147; Elbir ve Kandır, 2017: 23).

$A A R_{t}=\frac{1}{N} \sum_{i=1}^{N} A R_{i t}$

Formül 5'te yer alan $\mathrm{AR}_{\mathrm{i}, \mathrm{t}}$ örneklemde yer alan işletmelerin $t$ zamanındaki anormal getirilerini, $\mathrm{N}$ ise örneklemde yer alan işletme sayısını, AARt ise örneklemde yer alan ișletmelerin t zamanındaki ortalama anormal getirisini göstermektedir.

Bir olayın hissedar getirileri üzerindeki ortalama etkisini gösteren ve olay günü $(t=0)$ anormal getirilerinin 0 'a eşit olduğu sıfır hipotezinin $\left(\mathrm{H}_{0}\right)$ test edildiği $\mathrm{t}$ istatistiğinin hesaplanması olay çalışmasındaki diğer aşamadır (Brown ve Warner, 1985: 7). T testi, incelenen olayın pay getirilerine olan etkisiyle ilgilidir (Brown ve Warner, 1985: 7). Olay penceresinin 21 gün $(-10,+10)$, hesaplama döneminin 229 gün $(-239,-11)$ olarak belirlendiği bu çalışmada $\mathrm{t}$ istatistiği Formül 6'da gösterildiği şekilde hesaplanmıştır (Brown ve Warner, 1980: 251; Brown ve Warner, 1985: 7-8; Elbir ve Kandır, 2017: 2324);

$t=\frac{A A R_{t}}{\hat{S}\left(A A R_{t}\right)}$

$A A R_{t}=\frac{1}{N} \sum_{i=1}^{N} A R_{i t}$

$\hat{S}\left(A A R_{t}\right)=\sqrt{\left(\sum_{t=-239}^{t=-11}\left(A A R_{t}-\overline{A A R}_{t}\right)^{2}\right) / 228}$

$\overline{A A R}_{t}=\frac{1}{229} \sum_{t=-239}^{-11} A A R_{t}$

Formüllerde yer alan $\mathrm{N}$ örneklemde yer alan işletme sayısını ifade etmektedir. AAR $\mathrm{A}_{\mathrm{t}} \mathrm{t}$ dönemi ortalama anormal getirileri, $\hat{S}\left(A A R_{t}\right)$ ise ortalamaya göre ayarlanmış getiri modeli olması nedeniyle hesaplama dönemi ortalama anormal getiriler standart sapmasinı göstermektedir (Brown ve Warner, 1980: 250; Brown ve Warner, 1985: 8).

Piyasanın şokları kavrama ve özümseme durumunu tespit etmek ve başlangıçta dalgalanmaya neden olan belirsizliğin seyrini görmek için olay penceresinde Kümülatif Ortalama Anormal Getiriler (Cumulative Average Abnormal Returns-CAAR) hesaplanmaktadır (MacKinlay, 1997: 21; Mutan ve Topcu, 2009: 6; Elbir ve Kandır, 2017: 23). Kümülatif ortalama anormal 
getirilere Formül 5'te elde edilen ortalama anormal getirilerin toplanmasiyla (Formül 7) ulaşılmaktadır (Brown ve Warner, 1980: 228; Sakarya, 2011: 155; Elbir ve Kandır, 2017: 23).

$C A A R_{t}=\sum_{t=1}^{n} A A R_{t}$

Formülde CAARt belirli bir (t) başlangıç gününden (n) gününe kadar ortalama anormal getiriler (AAR) toplamını ifade etmektedir.

\section{BULGULAR}

Türkiye'de yaşanan 15 Temmuz Darbe girişimi, 2016 ve sonrasında gerçekleștirilen

Tablo 2: Ortalama Anormal Getiriler (AAR) sınır ötesi harekâtlar ve gerçekleșen seçimlerin turizm sektörü pay getirilerine etkisinin olay çalışması yöntemiyle incelendiği bu araștırmada elde edilen bulgular tablolar halinde sunulmaktadır. Ortalama getiri modeline göre saptanan anormal getirilerden hareketle hesaplanan ortalama anormal getiriler (AAR) ile $t$ istatistik değerleri Tablo 3'te yer almaktadır.

\begin{tabular}{|c|c|c|c|c|c|c|c|}
\hline Gün & 15 Temmuz & $\begin{array}{c}\text { Firat } \\
\text { Kalkanı }\end{array}$ & Zeytin Dalı & Barış Pınarı & $\begin{array}{l}\text { Genel } \\
\text { Seçim }\end{array}$ & Yerel Seçim & $\begin{array}{c}\text { İBB } \\
\text { Başkanlık } \\
\end{array}$ \\
\hline-10 & $\begin{array}{r}-0,021 \\
(-1,568)\end{array}$ & $\begin{array}{l}-0,002 \\
(-, 137)\end{array}$ & $\begin{array}{l}-0,007 \\
(-, 535)\end{array}$ & $\begin{array}{r}0,008 \\
(, 681)\end{array}$ & $\begin{array}{r}0,000 \\
(, 006)\end{array}$ & $\begin{array}{r}0,013 \\
(, 887)\end{array}$ & $\begin{array}{r}0,017 \\
(1,245) \\
\end{array}$ \\
\hline-9 & $\begin{array}{r}-0,005 \\
(-, 356) \\
\end{array}$ & $\begin{array}{l}-0,003 \\
(-, 180)\end{array}$ & $\begin{array}{r}0,004 \\
(, 283) \\
\end{array}$ & $\begin{array}{l}-0,001 \\
(-, 052)\end{array}$ & $\begin{array}{l}-0,005 \\
(-, 333)\end{array}$ & $\begin{array}{l}-0,003 \\
(-, 203) \\
\end{array}$ & $\begin{array}{l}-0,005 \\
(-, 357)\end{array}$ \\
\hline-8 & $\begin{array}{r}0,004 \\
(, 309)\end{array}$ & $\begin{array}{r}-0,011 \\
(-, 700)\end{array}$ & $\begin{array}{r}0,001 \\
(, 099)\end{array}$ & $\begin{array}{r}0,013 \\
(1,122)\end{array}$ & $\begin{array}{r}0,012 \\
(, 855)\end{array}$ & $\begin{array}{r}0,008 \\
(, 576)\end{array}$ & $\begin{array}{l}-0,007 \\
(-, 511)\end{array}$ \\
\hline-7 & $\begin{array}{r}0,004 \\
(, 296)\end{array}$ & $\begin{array}{r}0,015 \\
(0,956)\end{array}$ & $\begin{array}{r}0,002 \\
(, 165)\end{array}$ & $\begin{array}{r}0,007 \\
(, 565)\end{array}$ & $\begin{array}{r}0,010 \\
(, 663)\end{array}$ & $\begin{array}{l}-0,008 \\
(-, 519)\end{array}$ & $\begin{array}{r}0,002 \\
(, 142)\end{array}$ \\
\hline-6 & $\begin{array}{r}0,002 \\
(, 153)\end{array}$ & $\begin{array}{l}-0,001 \\
(-, 044)\end{array}$ & $\begin{array}{r}0,010 \\
(, 725)\end{array}$ & $\begin{array}{r}-0,009 \\
(-, 773)\end{array}$ & $\begin{array}{l}-0,010 \\
(-, 721)\end{array}$ & $\begin{array}{r}0,003 \\
(, 184)\end{array}$ & $\begin{array}{r}0,001 \\
(, 044)\end{array}$ \\
\hline-5 & $\begin{array}{r}0,004 \\
(, 311)\end{array}$ & $\begin{array}{l}-0,002 \\
(-, 118)\end{array}$ & $\begin{array}{r}-0,024 \\
(-1,811)\end{array}$ & $\begin{array}{l}-0,003 \\
(-, 237)\end{array}$ & $\begin{array}{r}0,005 \\
(, 376)\end{array}$ & $\begin{array}{r}-0,021 \\
(-1,415) \\
\end{array}$ & $\begin{array}{r}0,002 \\
(, 149)\end{array}$ \\
\hline-4 & $\begin{array}{r}0,022 \\
(1,597) \\
\end{array}$ & $\begin{array}{l}-0,006 \\
(-, 357)\end{array}$ & $\begin{array}{l}-0,003 \\
(-, 242) \\
\end{array}$ & $\begin{array}{r}0,037^{*} \\
(3,141)\end{array}$ & $\begin{array}{r}-0,017 \\
(-1,176) \\
\end{array}$ & $\begin{array}{r}0,001 \\
(, 041)\end{array}$ & $\begin{array}{r}0,026 \\
(1,895)\end{array}$ \\
\hline-3 & $\begin{array}{l}-0,001 \\
(-, 108)\end{array}$ & $\begin{array}{r}-0,000 \\
(-, 018)\end{array}$ & $\begin{array}{l}-0,001 \\
(-, 086)\end{array}$ & $\begin{array}{r}0,037^{*} \\
(3,174)\end{array}$ & $\begin{array}{l}0,003 \\
(, 212)\end{array}$ & $\begin{array}{r}-0,003 \\
(-, 196)\end{array}$ & $\begin{array}{l}-0,000 \\
(-, 010)\end{array}$ \\
\hline-2 & $\begin{array}{r}0,005 \\
(, 384)\end{array}$ & $\begin{array}{r}0,010 \\
(, 632)\end{array}$ & $\begin{array}{r}0,003 \\
(, 210)\end{array}$ & $\begin{array}{r}-0,013 \\
(-1,075)\end{array}$ & $\begin{array}{r}0,010 \\
(, 658)\end{array}$ & $\begin{array}{r}-0,035^{*} \\
(-2,438)\end{array}$ & $\begin{array}{r}0,000 \\
(, 027)\end{array}$ \\
\hline-1 & $\begin{array}{r}-0,009 \\
(-, 629)\end{array}$ & $\begin{array}{r}-0,013 \\
(-, 828)\end{array}$ & $\begin{array}{r}-0,024 \\
(-1,788) \\
\end{array}$ & $\begin{array}{r}-0,026^{*} \\
(-2,205)\end{array}$ & $\begin{array}{r}0,014 \\
(, 938) \\
\end{array}$ & $\begin{array}{r}0,008 \\
(, 528) \\
\end{array}$ & $\begin{array}{r}0,014 \\
(1,039) \\
\end{array}$ \\
\hline 0 & $\begin{array}{r}-0,109^{*} \\
(-7,949) \\
\end{array}$ & $\begin{array}{l}-0,006 \\
(-, 359) \\
\end{array}$ & $\begin{array}{r}0,027^{*} \\
(2,013) \\
\end{array}$ & $\begin{array}{l}-0,007 \\
(-, 560)\end{array}$ & $\begin{array}{r}-0,006 \\
(-, 386)\end{array}$ & $\begin{array}{r}0,008 \\
(, 525) \\
\end{array}$ & $\begin{array}{l}-0,009 \\
(-, 624)\end{array}$ \\
\hline+1 & $\begin{array}{r}0,031^{*} \\
(2,250)\end{array}$ & $\begin{array}{r}0,007 \\
(, 457)\end{array}$ & $\begin{array}{r}0,010 \\
(, 777)\end{array}$ & $\begin{array}{r}-0,015 \\
(-1,256)\end{array}$ & $\begin{array}{r}0,013 \\
(, 896)\end{array}$ & $\begin{array}{r}0,007 \\
(, 469)\end{array}$ & $\begin{array}{r}0,014 \\
(1,050) \\
\end{array}$ \\
\hline+2 & $\begin{array}{r}-0,032^{*} \\
(-2,370)\end{array}$ & $\begin{array}{r}-0,001 \\
(-, 063)\end{array}$ & $\begin{array}{r}0,022 \\
(1,700)\end{array}$ & $\begin{array}{c}-0,000 \\
(-, 019)\end{array}$ & $\begin{array}{r}0,009 \\
(, 596)\end{array}$ & $\begin{array}{r}0,003 \\
(, 228)\end{array}$ & $\begin{array}{l}-0,007 \\
(-, 508)\end{array}$ \\
\hline+3 & $\begin{array}{r}-0,044^{*} \\
(-3,230)\end{array}$ & $\begin{array}{l}-0,011 \\
(-, 676)\end{array}$ & $\begin{array}{l}-0,006 \\
(-, 462) \\
\end{array}$ & $\begin{array}{r}-0,050^{*} \\
(-4,279) \\
\end{array}$ & $\begin{array}{r}0,019 \\
(1,328) \\
\end{array}$ & $\begin{array}{r}0,001 \\
(, 061) \\
\end{array}$ & $\begin{array}{l}-0,003 \\
(-, 239) \\
\end{array}$ \\
\hline+4 & $\begin{array}{r}0,035 * \\
(2,545) \\
\end{array}$ & $\begin{array}{r}0,009 \\
(, 565) \\
\end{array}$ & $\begin{array}{r}0,024 \\
(1,818) \\
\end{array}$ & $\begin{array}{r}0,041 * \\
(3,488) \\
\end{array}$ & $\begin{array}{r}0,027 \\
(1,884) \\
\end{array}$ & $\begin{array}{r}0,019 \\
(1,290) \\
\end{array}$ & $\begin{array}{l}-0,003 \\
(-, 235)\end{array}$ \\
\hline+5 & $\begin{array}{r}0,039^{*} \\
(2,821)\end{array}$ & $\begin{array}{r}0,003 \\
(, 192)\end{array}$ & $\begin{array}{r}0,017 \\
(1,271)\end{array}$ & $\begin{array}{r}0,019 \\
(1,628)\end{array}$ & $\begin{array}{l}-0,001 \\
(-, 035)\end{array}$ & $\begin{array}{r}0,005 \\
(, 357)\end{array}$ & $\begin{array}{r}0,011 \\
(, 779)\end{array}$ \\
\hline+6 & $\begin{array}{l}-0,006 \\
(-, 471)\end{array}$ & $\begin{array}{r}0,011 \\
(, 692)\end{array}$ & $\begin{array}{l}-0,005 \\
(-, 358)\end{array}$ & $\begin{array}{r}-0,013 \\
(-1,113)\end{array}$ & $\begin{array}{r}0,006 \\
(, 435) \\
\end{array}$ & $\begin{array}{r}-0,007 \\
(-, 501)\end{array}$ & $\begin{array}{r}0,006 \\
(, 434)\end{array}$ \\
\hline
\end{tabular}




\begin{tabular}{|l|r|r|r|r|r|r|r|}
\hline+7 & 0,005 & $-0,001$ & $-0,007$ & 0,022 & 0,018 & 0,013 & 0,010 \\
& $(, 393)$ & $(, 042)$ & $(-, 562)$ & $(1,863)$ & $(1,218)$ & $(, 919)$ & $(, 749)$ \\
\hline \multirow{2}{*}{+8} & 0,019 & 0,002 & $-0,017$ & 0,004 & 0,013 & 0,002 & 0,016 \\
& $(1,369)$ & $(, 136)$ & $(-1,310)$ & $(, 372)$ & $(, 915)$ & $(, 152)$ & $(1,148)$ \\
\hline \multirow{2}{*}{+9} & 0,007 & $-0,002$ & $-0,002$ & 0,012 & 0,002 & $-0,002$ & 0,018 \\
& $(, 489)$ & $(-, 146)$ & $(-, 170)$ & $(1,062)$ & $(, 111)$ & $(-, 150)$ & $(1,338)$ \\
\hline \multirow{2}{*}{+10} & 0,017 & 0,010 & 0,009 & 0,021 & $-0,003$ & $-0,013$ & $-0,011$ \\
& $(1,235)$ & $(, 636)$ & $(, 676)$ & $(1,819)$ & $(, 203)$ & $(-, 876)$ & $(-, 812)$ \\
\hline \multicolumn{2}{|l}{ t değerleri parantez içinde yer almaktadır. \% 5 düzeyinde anlamllı̆̆ı̆ göstermektedir. } & & \\
\hline
\end{tabular}

Son yıllarda yaşanan önemli olaylardan Türkiye ile Rusya arasında yaşanan Uçak Krizine Turizm endeksi ve paylarının olay sonrası dönemde yatırımcı tepkisinin pozitif olduğu Şahin vd. (2017) ile Çelik ve Koç (2019) tarafından yapılan çalışmalarda tespit edilmiştir. Bu çalışmada ise Türkiye'de 2016 sonrasında 15 Temmuz Darbe Girişimi, Sınır Ötesi Harekâtlar ve Seçimlere turizm sektörü yatırımcı tepkileri incelenmiştir. Olaylara ilişkin bulguların yer aldığı Tablo 3 incelendiğinde; en yüksek olay günü negatif AAR $(-0,109) 15$ Temmuz darbe girişiminde gözlenmiştir. 15 Temmuz Darbe Girişimi öncesinde AAR anlamlı değilken, olay sonrası 5. güne kadar tüm günlerde AAR anlamlıdır. 1. 4. ve 5. günlerde AAR pozitif, 2 ve 3 . günde ise AAR negatiftir. Bu yönüyle bu çalışmada Chang ve Zeng (2011: 172-173) tarafindan saptanan terör olaylarının ulus ruhunu ve yatırımcı duyarlılığını etkileyerek pozitif getirilere sebep olduğu bulgusunu destekleyen zayıf bulgular elde edilmiştir. Fırat Kalkanı Harekâtı AAR bulguları incelendiğinde olay penceresinde anlamlı bir AAR gözlenmemiştir. Çömlekçi ve Şahin (2019)'in çalışmasında BİST100 endeksinin Firat Kalkanı Harekâtı'na olay günü anormal getiriler gösterdiği bulgusuna karşın turizm sektörü yatırımcıları tepkisinin BİST100 endeksinden farklı olduğu tespit edilmiştir. Zeytin Dalı Harekâtında sadece olay günü anlamlı AAR $(0,027)$ gözlenmiştir. Barış Pınarı Harekâtına ilişkin bulgular incelendiğinde olay günü öncesi 4 . gün $(0,037)$ ve 3 . gün $(0,037)$ pozitif $A A R$ gözlenirken olay sonrası 3 . gün negatif $(-$ $0,050)$, 4. gün pozitif (0.041) AAR gözlenmiştir.

Çalışmada incelenen seçimlere yönelik bulgular incelendiğinde Cumhurbaşkanlığı ve Genel Seçiminde olay penceresinde anlamlı bir AAR gözlenmemiştir. 2019 Yerel seçimlerinde olay öncesinde 2. gün AAR $(-0,035)$ anlamlıyken, olay günü ve sonrasinda AAR anlamsızdır. İstanbul Büyükşehir Belediye Başkanlık Seçimlerinde ise olay günü anlamlı bir AAR saptanmamış olup sadece olay öncesinde 4. gün anlamlı pozitif $\operatorname{AAR}(0,026)$ gözlenmiştir.

Kümülatif anormal getiri, şirketler tarafından yapılan duyuruların toplam etkisini gösterirken; anormal getiri, bu duyuruların her bir gün için ortalama piyasa değeri üzerindeki etkisini belirlemek için kullanılmaktadır (Nagm ve Kautz, 2008: 70; akt. Elbir ve Kandır, 2017: 25). Turizm işletmelerinin olay penceresi $(-10,+10)$ kümülatif ortalama aşırı getirileri (CAAR) Tablo 4'teki gibidir.

Tablo 3: Kümülatif Ortalama Anormal Getiriler (CAAR)

\begin{tabular}{|l|c|r|r|r|r|r|r|}
\hline Gün & $\begin{array}{c}15 \\
\text { Temmuz }\end{array}$ & $\begin{array}{c}\text { FIrat } \\
\text { Kalkanı }\end{array}$ & $\begin{array}{c}\text { Zeytin } \\
\text { Dalı }\end{array}$ & $\begin{array}{c}\text { Barış } \\
\text { Pınarı }\end{array}$ & $\begin{array}{c}\text { Genel } \\
\text { Seçim }\end{array}$ & $\begin{array}{c}\text { Yerel } \\
\text { Seçim }\end{array}$ & $\begin{array}{c}\text { İBB } \\
\text { Başkanlık }\end{array}$ \\
\hline-10 & $-0,021$ & $-0,002$ & $-0,007$ & 0,008 & 0,000 & 0,013 & 0,017 \\
\hline-9 & $-0,026$ & $-0,005$ & $-0,003$ & 0,007 & $-0,005$ & 0,010 & 0,012 \\
\hline-8 & $-0,022$ & $-0,016$ & $-0,002$ & 0,020 & 0,008 & 0,018 & 0,005 \\
\hline-7 & $-0,018$ & $-0,001$ & 0,000 & 0,027 & 0,017 & 0,011 & 0,007 \\
\hline-6 & $-0,016$ & $-0,002$ & 0,010 & 0,018 & 0,007 & 0,013 & 0,008 \\
\hline
\end{tabular}


İzmir İktisat Dergisi (İzmir Journal of Economics) , Yll:2020, Cilt:35, Sayı:4, ss. 839-856

\begin{tabular}{|l|r|r|r|r|r|r|r|}
\hline-5 & $-0,012$ & $-0,004$ & $-0,014$ & 0,015 & 0,012 & $-0,007$ & 0,010 \\
\hline-4 & 0,010 & $-0,009$ & $-0,017$ & 0,052 & $-0,005$ & $-0,007$ & 0,036 \\
\hline-3 & 0,009 & $-0,010$ & $-0,019$ & 0,089 & $-0,002$ & $-0,009$ & 0,036 \\
\hline-2 & 0,014 & 0,001 & $-0,016$ & 0,077 & 0,008 & $-0,045$ & 0,036 \\
\hline-1 & 0,005 & $-0,013$ & $-0,039$ & 0,051 & 0,021 & $-0,037$ & 0,050 \\
\hline $\mathrm{t}$ & $-0,103$ & $-0,018$ & $-0,013$ & 0,044 & 0,016 & $-0,029$ & 0,042 \\
\hline+1 & $-0,073$ & $-0,011$ & $-0,002$ & 0,030 & 0,029 & $-0,023$ & 0,056 \\
\hline+2 & $-0,105$ & $-0,012$ & 0,020 & 0,029 & 0,038 & $-0,019$ & 0,049 \\
\hline+3 & $-0,149$ & $-0,023$ & 0,014 & $-0,021$ & 0,057 & $-0,018$ & 0,046 \\
\hline+4 & $-0,114$ & $-0,014$ & 0,038 & 0,020 & 0,084 & 0,000 & 0,043 \\
\hline+5 & $-0,076$ & $-0,011$ & 0,055 & 0,039 & 0,084 & 0,005 & 0,053 \\
\hline+6 & $-0,082$ & 0,000 & 0,050 & 0,026 & 0,090 & $-0,002$ & 0,059 \\
\hline+7 & $-0,077$ & 0,001 & 0,043 & 0,048 & 0,108 & 0,012 & 0,070 \\
\hline+8 & $-0,058$ & 0,003 & 0,025 & 0,052 & 0,121 & 0,014 & 0,085 \\
\hline+9 & $-0,051$ & 0,001 & 0,023 & 0,065 & 0,123 & 0,012 & 0,104 \\
\hline+10 & $-0,035$ & 0,011 & 0,032 & 0,086 & 0,120 & $-0,001$ & 0,093 \\
\hline
\end{tabular}

Olay penceresinde $(-10,+10)$ turizm sektörü işletmeleri kümülatif ortalama anormal getirileri (CAAR) incelendiğinde 15 Temmuz darbe girişiminde $(-0,035)$ ve yerel seçimde negatif CAAR gözlenmiştir. İncelenen diğer olaylarda pozitif CAAR gözlenirken en yüksek pozitif CAAR Cumhurbaşkanlığı ve Milletvekili Genel seçiminde $(0,120)$ gözlenmiştir. 15 Temmuz darbe girişiminde olay sonrası CAAR'lar negatifken, Zeytin Dalı ve Barış Pınarı Harekâtlarında, Genel Seçim ve İBB Başkanlık Ara Seçimde yoğunlukla pozitiftir.

Ortalama getiri yöntemine göre hesaplanan anormal getirilere dayalı olarak olay penceresinde farklı aralıklar açısından kümülatif anormal getiriler (CAAR) hesaplanarak Tablo 5'te sunulmuştur.

Tablo 5 incelendiğinde olay gününde $(\mathrm{t}=0)$ Zeytin Dalı Harekâtı ve Yerel seçim dışında tüm olaylarda negatif CAAR gözlenirken olay penceresinde $-10,+10$ aralığında 15 Temmuz darbe girişimi ve Yerel Seçimde CAAR negatiftir. $-5,+5$ aralığında 15 Temmuz darbe girişimi, Fırat Kalkanı Harekâtı ve Yerel Seçimde CAAR negatiftir. $-3,+3$ aralığında 15 Temmuz, Fırat Kalkanı, Barış Pınarı ve Yerel Seçimde negatif CAAR gözlenirken, $-1,+1$ aralığında sadece 15 Temmuz, Fırat Kalkanı ve Barıș Pınarı Harekâtlarında negatif CAAR gözlenmiştir.

Tablo 4: Farklı Aralıklarda Kümülatif Ortalama Anormal Getiriler

\begin{tabular}{|l|r|r|r|r|r|r|r|}
\hline & $\begin{array}{c}15 \\
\text { Temmuz }\end{array}$ & $\begin{array}{c}\text { Firat } \\
\text { Kalkanı }\end{array}$ & $\begin{array}{c}\text { Zeytin } \\
\text { Dalı }\end{array}$ & \multicolumn{1}{c|}{$\begin{array}{c}\text { Barış } \\
\text { Pınarı }\end{array}$} & $\begin{array}{c}\text { Genel } \\
\text { Seçim }\end{array}$ & \multicolumn{1}{c|}{$\begin{array}{c}\text { Yerel } \\
\text { Seçim }\end{array}$} & \multicolumn{1}{c|}{$\begin{array}{c}\text { IBBB } \\
\text { Başkanlık }\end{array}$} \\
\hline$-10,+10$ & $-0,035$ & 0,011 & 0,032 & 0,086 & 0,120 & $-0,001$ & 0,093 \\
\hline$-5,+5$ & $-0,060$ & $-0,009$ & 0,045 & 0,021 & 0,077 & $-0,008$ & 0,046 \\
\hline$-3,+3$ & $-0,159$ & $-0,014$ & 0,031 & $-0,073$ & 0,062 & $-0,012$ & 0,010 \\
\hline$-1,+1$ & $-0,029$ & $-0,012$ & 0,013 & $-0,047$ & 0,021 & 0,022 & 0,020 \\
\hline 0 & $-0,109$ & $-0,006$ & 0,027 & $-0,007$ & $-0,006$ & 0,008 & $-0,009$ \\
\hline$-10,-1$ & 0,005 & $-0,013$ & $-0,039$ & 0,051 & 0,021 & $-0,037$ & 0,050 \\
\hline$-5,-1$ & 0,021 & $-0,011$ & $-0,049$ & 0,033 & 0,015 & $-0,051$ & 0,043 \\
\hline$-3,-1$ & $-0,005$ & $-0,003$ & $-0,022$ & $-0,001$ & 0,026 & $-0,031$ & 0,014 \\
\hline$+1,+3$ & $-0,046$ & $-0,004$ & 0,027 & $-0,065$ & 0,041 & 0,011 & 0,004 \\
\hline$+1,+5$ & 0,028 & 0,008 & 0,067 & $-0,005$ & 0,068 & 0,035 & 0,012 \\
\hline$+1,+10$ & 0,069 & 0,029 & 0,045 & 0,042 & 0,104 & 0,028 & 0,051 \\
\hline
\end{tabular}


Olay öncesi $-10,-1$ aralığında 15 Temmuz, Barıș Pınarı, Genel Seçim ve İstanbul Büyükşehir Belediye Başkanlık ara seçiminde CAAR pozitif iken diğer olaylarda negatiftir. -5 , -1 aralığında Fırat Kalkanı, Zeytin Dalı ve Yerel Seçimlerde negatif CAAR gözlenmişken, $-3,-1$ aralığında Genel Seçim ve İstanbul Büyükşehir Belediye Başkanlık ara seçimlerinde pozitif, diğer olaylarda negatif CAAR saptanmıştır. Yapa ve Akbulut (2018) genel seçimin erkene alınması duyurusunun BİST100 endeksinde olumlu algılandığına ve getirilerin duyuru sonrasında pozitif eğimli olduğunu, Nezerwe (2013) Mısır'da başkanlı seçimlerinin getirileri pozitif etkilediğini tespit etmiștir. $\mathrm{Bu}$ çalışmada elde edilen bulgular siyasi olaylarla ilgili yapılan çalışmaları destekler niteliktedir.

Olay sonrası dönemde CAAR genel olarak pozitif olup, +1, +3 aralığında 15 Temmuz, Fırat Kalkanı ve Barış Pınarı Harekâtlarında negatif ve $+1,+5$ aralığında sadece Barış Pınarı Harekâtında negatif CAAR gözlenmiştir. +1, +10 aralığında ise tüm olaylarda pozitif CAAR saptanmıştır.

\section{SONUÇ}

$\mathrm{Bu}$ çalışmada, turizm sektörü pay yatırımcılarının Türkiye'de yaşanan terör, askeri ve politik temelli çeşitli olaylara tepkilerinin olay çalışması yöntemiyle tespit edilmesi amaçlanmıştır. Bu amaç kapsamında 2016 yılı sonrasında yaşanan 15 Temmuz Darbe Girișimi, Suriye'nin kuzeyinde terör gruplarına karşı gerçekleştirilen harekâtlar ve gerçekleşen seçimler olmak üzere yedi olay incelenmiştir. Ortalama getiri modeline göre tespit edilen anormal getirilere dayalı olarak olay öncesi 10 gün ve olay sonrası 10 gün ortalama anormal getiriler (AAR), kümülatif anormal getiriler (CAAR) ve olay penceresinde farklı aralıklarda kümülatif anormal getiriler hesaplanmıştır.

Çalışma sonuçlarına göre, 15 Temmuz Darbe Girişimi olay günü ve olay sonrası ikinci ve üçüncü günde negatif anormal getiriler gözlenmiştir. Olay sonrası birinci, dördüncü ve beşinci günlerde ise anormal getiriler pozitiftir. Olay çevresi $-10,+10 ;-5,+5 ;-3,+3$ ve
$-1,+1$ arası CAAR negatif olan olayda olay sonrası üç günlük dönemde yine negatif kümülatif ortalama anormal getiri gözlenmiştir. $+1,+5$; ve $+1,+10$ günlük dönemlerde ise pozitif kümülatif anormal getiriler gözlenmiştir. Bu sonuç 15 Temmuz darbe girişiminin genel olarak yatırımcılarda kısa dönemli bir panik yarattığı ancak olay sonrası kısa dönemde yeniden dengelenmenin yaşandığına işaret etmektedir.

Suriye'nin kuzeyinde DEAŞ ve PKK/KCK/PYDYPG terör gruplarına karşı yapılan Fırat Kalkanı, Zeytin Dalı ve Barış Pınarı harekâtlarına yönelik bulgular incelendiğinde; Fırat Kalkanı Harekâtı'nda olay penceresinde anlamlı ortalama anormal getiri (AAR) gözlenmemiştir. Zeytin Dalı Harekâtı'nda ise olay günü pozitif ortalama anormal getiri gözlenmiş olup diğer günlerde anlamlı ortalama anormal getiri saptanmamıştır. $\mathrm{Bu}$ bulgu, yatırımcıların, harekâtın terörden kaynaklanan güvenlik riskinin bertaraf edilerek sektöre etkilerinin olumlu olacağı inancına sahip olduklarına işaret niteliğindedir. Barıș Pınarı Harekâtı'na yönelik bulgular incelendiğinde olay öncesi dördüncü ve üçüncü günlerde, olay sonrası dördüncü gün pozitif, olay öncesi birinci gün ve olay sonrası üçüncü gün negatif ortalama anormal getiri gözlenirken, olay çevresinde $(-10,+10)$ pozitif kümülatif ortalama anormal getiri (CAAR) gözlenmiştir. Olay çevresinde en yüksek CAAR genel seçim ve İBB Başkanlık ara seçim sonrasında Barış Pınarı Harekâtındadır. Harekâtlar açısından gözlenen bulgular olay günü ve penceresinde gözlenen diğer şartların sabit olduğu varsayıldığında genel olarak ülke güvenlik riskini ortadan kaldırarak turizm talebinde etkili olan temel faktörlerden güvenliğin sağlanması ve terör kaynaklı güvenlik riskinin azaltılmasına katkı sağladığı ve pay getirilerine olumlu yansıdığı ifade edilebilir.

Seçimlere yönelik bulgular incelendiğinde; Cumhurbaşkanlığı ve Milletvekili Genel Seçimi çevresinde ortalama anormal getiriler $t$ değerleri istatistiki olarak anlamsızdır. $\mathrm{Bu}$ 
durum genel seçime bağlı olarak yatırımcılar tarafından olay öncesi, günü ve sonrası hiçbir gün anormal getiri elde etmediklerini göstermektedir. Diğer yandan yerel seçim öncesi ikinci gün negatif ortalama anormal getiri (AAR), ara seçimde ise olay öncesi dördüncü gün pozitif AAR tespit edilmiştir. Çalışmada seçimlere ilişkin bulgular turizm sektörü ortalama anormal getirilerin genel seçim ve ara seçim çevresinde pozitif olduğunu yerel seçim çevresinde ise dalgalı olduğunu göstermektedir. İncelenen seçimlerin hiçbirinde olay günü ve sonrasında istatistiki olarak anlamlı ortalama anormal getiri gözlenmemesi turizm sektörü paylarının siyasi olaylardan çok askeri ve güvenlik riski ile ilgili olaylardan etkilendiğine işaret etmektedir.

Son yıllarda Uçak Krizi dışında 2016'dan sonra yaşanan önemli terör, politik ve askeri olayların incelendiği bu çalışmada elde edilen bulgular genel olarak, zengin arz kaynaklarına sahip olan Türk turizminde, turizm sektörü pay getirilerinde etkili olan temel unsurun güvenlik riski olduğunu göstermektedir. Türk turizm ișletmeleri pay getirilerinin terör, politik ve askeri olaylara yatırımcı tepkisinin ölçüldüğü bu çalışmanın literatürdeki eksikliğin giderilmesi yönünden katkı sağlamaktadır. Deprem ve terör saldırılarında gözlenen düşük pay performansı, otel satış gelirlerinde yaşanan kayıptan kaynaklanırken, salgının otel pay getirilerine olumsuz etkisi yalnızca satış gelirlerindeki daralmadan değil aynı zamanda para politikasından etkilenmektedir. Dolayısıyla bu çalışmadan elde edilen bulgular olay bazlı olup gelecek çalışmalarda olay penceresinde ve olay döneminde gözlenen diğer gelişme ve olayların etkileriyle birlikte incelenmesi, riski dikkate alan bunun yanında diğer modellere dayalı olarak getirilerin hesaplanarak yatırımcı tepkilerinin daha hassas bir şekilde ölçülmesi literatürdeki eksikliğin giderilmesini sağlayacaktır. Ayrıca gelecek çalışmalarda gerek literatürdeki eksikliğin giderilmesi gerekse ilgili taraflara sağlayacağ k katkılar nedeniyle çalışmada ele alınan ve benzer olaylarda diğer sektör yatırımcı tepkilerinin incelenmesi önerilebilir.

\section{REFERANSLAR}

Akçakaya, M. ve Özdemir, A. (2018). Cumhurbașkanlığı Hükümet Sistemi ve Siyasal İstikrar, Üçüncü Sektör Sosyal Ekonomi, 53(3), 922-944.

Alkan, H. (2016). 15 Temmuz'u Anlamak: Parametreler ve Sonuçlar, Bilig, 76, 253-272.

Armitage, S. (1995). Event Study Methods and Evidence on Their Performance, Journal of Economic Surveys, 8(4). 25-52.

Avdagiç, Ş. (2019). “İstanbul 2018'de de ekonominin lokomotifi oldu”, 30.12.2019 tarihinde

http://www.hurriyet.com.tr/ekonomi/istanb ul-2018de-de-ekonominin-lokomotifi-oldu41069604 adresinden erişildi.

Bahar, E. ve İstanbullu Dinçer, F. (2019). Ziyaretçi Sayılarının Analizi ile İstanbul'un Turizm Pazarlarının Değerlendirilmesi, Turizm ve Araştırma Dergisi, 8(1). 20-41.
Berman, G., Brooks, R. ve Davidson, S. (2000). The Sydney Olympic Games Announcement and Australian Stock Market Reaction, Applied Ecconomics Letters, 7, 781-784.

Borde, S. F., Byrd, A. K. ve Atkinson, S. M. (1999). Stock Price Reaction to Dividend İncreases in The Hotel and Restaurant Sector, Journal of Hospitality \& Tourism Research, 23(1). 40-52.

Brown, S. J. ve Warner, J. B. (1980). Measuring Security Price Performance, Journal of Financial Economics, 8, 205-258.

Brown, S. J. ve Warner, J. B. (1985). Using Daily Stock Returns, The Case of Event Studies, Journal of Financial Economics, 14, 3-31.

Chang, C. ve Zeng, Y. Y. (2011). Impact of Terrorism on Hospitality Stocks and the Role of Investor Sentiment, Cornell Hospitality Quarterly, 52(2), 165-175. 
Chen, A. H. ve Siems, T. F. (2007). The Effects of Terrorism on Global Capital Markets. T. Brück (Ed.), The Economic Analysis of Terrorism içinde (ss.83-106). New York: Routledge.

Chen, M.-H. (2011). The Response of Hotel Performance to International Tourism Development and Crisis Events, International Journal of Hospitality Management, 30, 200212.

Chen, M.-H., Jang, S.C. (S.) ve Kim, W. G. (2007). The Impact of the SARS Outbreak on Taiwanese Hotel Stock Performance: An Event-Study Approach, Hospitality Management, 26, 200-212.

Cnn Türk (2019). "Mehmetçik Afrin şehir merkezinde - Zeytin Dalı Harekatı 1. Yıl - 6", 25.12.2019 tarihinde https://www.cnnturk.com/video/dunya/meh metcik-afrin-sehir-merkezinde-zeytin-daliharekati-1-yil-6 adresinden erişildi.

Çelik, M. S. ve Koç, R. (2019). Türkiye ve Rusya Arasındaki Uçak Krizinin Borsa İstanbul (BİST) Turizm ve Enerji Şirket Hisselerine Etkisi Üzerine Bir Event Study Analizi, Niğde Ömer Halisdemir Üniversitesi Sosyal Bilimler Enstitüsü Dergisi, 1(1), 1-15.

Çıtak, L. ve Ersoy, E. (2016). Firmaların BIST Sürdürülebilirlik Endeksine Alınmasına Yatırımcı Tepkisi: Olay Çalışması ve Ortalama Testleri ile Bir Analiz, Uluslararası Alanya İșletme Fakültesi Dergisi, 8(1), 43-57.

Çömlekçi, İ. ve Şahin, Ö. (2019). Güç Unsurları ile Pay Senedi Getirileri Arasındaki İlişki: Olay Çalışması (Event Study), Uluslararası Yönetim Íktisat ve Issletme Dergisi, 15(1), 46-60.

Demir, E. ve Ersan, O. (2018). The Impact of Economic Policy Uncertainty on Stock Returns of Turkish Tourism Companies, Current Issues in Tourism, 21(8), 847-855.

Dogru, T. ve Sirakaya-Turk, E. (2016). Stock Market Valuation of Hotel Firms' Sustainable Initiatives, The Journal of Hospitality Financial Management, 24, 127-132.
Elbir, G. ve Kandır, S. Y. (2017). Yatırım Duyurularının Pay Getirileri Üzerindeki Etkisinin İncelenmesi: Demir-Çelik Sektörü Örneği, Ekonomi Bilimleri Dergisi, 9(1), 16-32.

Hürriyet (2019). "MSB'den 'Barış Pınarı Harekatı' Açıklaması" 20.01.2019 tarihinde http://www.hurriyet.com.tr/gundem/msbde n-baris-pinari-harekati-aciklamasi-41386973 adresinden erişildi.

Investing.com (2019). 12.12.2019 tarihinde https://tr.investing.com/ adresinden erişildi.

İçişleri Bakanlığı (2017). "Türkiye'nin DEAŞ ile Mücadelesi", $\quad 30.12 .2019 \quad$ tarihinde https://www.icisleri.gov.tr/kurumlar/icisleri. gov.tr/IcSite/strateji/deneme/YAYINLAR/\%C 4\%B0\%C3\%87ER\%C4\%B0K/deas\%CC\%A7 $\% 20$ frans\%C4\%B1zca.pdf adresinden erişildi.

Kaderli, Y. (2007). Yapılan İhracat Bağlantılarının İlgili Firmaların Hisse Senedi Getirileri Üzerindeki Etkisinin Olay Etüdü İle İncelenmesi: İstanbul Menkul Kiymetler Borsası'ndaki Bazı Firmalar Üzerine Bir Uygulama, Muhasebe ve Finansman Dergisi, 36, 144-154.

Kamuyu Aydınlatma Platformu (2019). 12.12.2019 tarihinde https://www.kap.org.tr/tr/Sektorler adresinden erişildi.

Karagöl, E. T. (2016). 15 Temmuz Darbe Girişimi ve Türkiye Ekonomisi, Adam Akademi, 6(2), 37-50.

Kaya, İ., Keskin Köylü, M. ve Günay, B. (2017). 15 Temmuz Darbe Girişiminin BİST 30/100 Endeksleri Üzerine Etkisinin Olay Çalışması (Event Study) Yöntemi ile Analizi, Uluslararası İktisadi ve Ídari Bilimler Dergisi, 3(2). 54-67.

Kim, S. H., Kim, W. G. ve Hancer, M. (2009). Effect of IT Investment Announcements on the Market Value of Hospitality Firms Using Event Study Methodology, Tourism Economics, 15(2), 397-411.

Kurt, V. (2019). “5 Soru: Barıș Pınarı Harekâtı”, 25.12.2019 tarihinde 
https://www.setav.org/5-soru-baris-pinariharekati/ www.setav.org adresinden erișildi.

MacKinlay, A. C. (1997). Event Studies in Economics and Finance, Journal of Economic Literature, 35(March 1997), 13-39.

Madanoglu, M., Olsen, M. D. ve Kwansa, F. A. (2010). The Impact of Terrorist Bombings on the Market Values of Hospitality and Tourism Enterprises: Global Evidence from Turkey, Spain and Indonesia, Journal of Hospitality Financial Management, 15(2), 1-20.

Milli Güvenlik Kurulu (2017). "29 Mart 2017 Tarihli Toplantı Sonrası Yazılı Açıklama", 25.12.2019 tarihinde https://www.mgk.gov.tr/index.php/29-mart2017-tarihli-toplanti adresinden erişildi.

Milli Savunma Bakanlığı (2019a). "Barış Pınarı Harekâtı Başladı”, Basın Açıklaması, 9 Ekim 2019, Ankara, 25.12.2019 tarihinde https://www.msb.gov.tr/SlaytHaber/910201 9-53737 adresinden erişildi.

Milli Savunma Bakanlığı (2019b). “Elektrik Trafoları ve Hatlar Onarılıyor, Su Kuyuları Aktif Hale Getiriliyor", Basın Açıklaması, 15.12.2019 Ankara, 25.12.2019 tarihinde https://www.msb.gov.tr/SlaytHaber/141220 19-04423 adresinden erişildi.

Mutan, O. ve Topcu, A. (2009). Türkiye Hisse Senedi Piyasasının 1990-2009 Tarihleri Arasında Yaşanan Beklenmedik Olaylara Tepkisi, Sermaye Piyasası Kurulu Araştırma Raporu, Araştırma Dairesi: 22.06.2009 OCM 2009/01.

Nagm, F. ve Kautz, K. (2008). The Market Value Impact of IT Investment Announcements - An Event Study, Journal of Information Technology Theory and Application, 9(3), 62-80.

Nezerwe, Y. (2013). Presidental Elections and Stock Returns in Egypt, Review of Business and Finance Studies, 4(2), 63-68.

Nicolau, J. L. (2002). Assessing New Hotel Openings Through an Event Study, Tourism Management, 23, 47-54.
Peterson, P. P. (1989). Event Studies: A Review of Issues and Methodology, Quarterly Journal of Business and Economics, 28(3), 36-66.

Qin, M., Tang, C.-H. (H.). Jang, S. (S.). ve Lehto, $X$. (2017). Mobile App Introduction and Shareholder Returns, Journal of Hospitality and Tourism Management, 31, 173-180.

Ross, S. A., Westerfield, R. W. ve Jaffe, J. F. (2002). Corporate Finance, (6th edt.). USA: The McGraw-Hill Companies, Inc.

Sakarya, Ș. (2011). İMKB Kurumsal Yönetim Endeksi Kapmasındaki Şirketlerin Kurumsal Yönetim Derecelendirme Notu ve Hisse Senedi Getirileri Arasındaki İlişkinin Olay Çalışması (Event Study) Yöntemi ile Analizi, ZKÜ Sosyal Bilimler Dergisi, 7(13), 147-162.

Sheel, A. ve Zhong, Y. (2005). Cash Dividend Announcements and Abnormal Returns in the Lodging and Restaurant Sectors: An Empirical Examination, The Journal of Hospitality Financial Management, 13(1), 49-58.

Szutowski, D. ve Bednarska, M. A. (2014). Short-Term Effects of Innovations on Tourism Enterprise Market Value: Event Study Approach, F. Dias, S. Oliveira, J. Kosmaczewska ve Â. Pereira (Ed.), New Trends in Tourism Research: A Polish Perspective, içinde (ss. 205217). Portugal: GITUR

Şahin, E., Konak, F. ve Karaca, S. S. (2017). Türkiye ve Rusya Arasındaki "Uçak Krizinin" Borsa İstanbul Gıda, İçecek ve Turizm Endeksleri Üzerine Etkisi, Business and Economics Research Journal, 8(3), 473-485.

TCCB, (2018). "15 Temmuz Darbe Girişimi ve Milletin Zaferi", 25.12.2019 tarihinde https://www.tccb.gov.tr/assets/dosya/15Te mmuz/15temmuz_tr.pdf adresinden erişildi.

Thorbacke, W. (1997). On Stock Market Returns and Monetary Policy, The Journal of Finance, 52(2), 635-654.

Turan, A. M. (2018). Türkiye'nin Yeni Yönetim Düzeni: Cumhurbaşkanlığı Hükümet Sistemi, Social Sciences Research Journal, 7(3), 42-91. 
Tüik (2019). "Adrese Dayalı Nüfus Kayıt İstatistikleri", http://tuik.gov.tr/PreTablo.do?alt_id=1059

Türk Silahlı Kuvvetleri (2018). "Zeytin Dalı Harekatı", Basın Açıklaması, 20.01.2018, Ankara, 30.12.2019 tarihinde https://www.tsk.tr/Home/Detay/373

adresinden erişildi.

Ulutaş, U. ve Duran, B. (2017). “Türkiye'nin DEAŞ’la Mücadelesinin Kritik Dönemeci: Fırat Kalkanı Harekâtı", 25.12.2019 tarihinde https://www.setav.org/turkiyenin-deaslamucadelesinin-kritik-donemeci-firat-kalkaniharekati/ adresinden erişildi.

Veraros, N., Kasimati, E. ve Dawson, P. (2004). The Olympic Games Announcement and Its Effect on the Athens and Milan Stock Exchanges, Applied Ecconomics Letters, 11, 749-753.

Yapa, K. ve Akbulut, İ. (2018). 2018 Cumhurbaşkanlığı ve Genel Seçimlerinin Piyasaya Etkileri, 6. SCF International Conference on "Economic and Social Impacts of Globalization and Liberalization", Antalya: 1113 Ekim 2018.

Yaşar, G. ve Yaşar, M. M. (2017). Türkiye Rusya Uçak Krizi Sonrasında Türkiye Turizmi, VII. Uluslararası Karadeniz Sempozyumu "Türk Rus İlişkileri”, 19-20 Ekim 2017, Giresun, Türkiye.

Yeltin, H. (2018). Türkiye'nin Suriye Krizine Karşı Güvenlik Arayışlarına Bir Örnek: Fırat
Kalkanı Harekâtı, Econder Uluslararası Akademik Dergi, 2(2), 200-214.

Yenişehirlioğlu, E., Erdoğan, Ç., Polat, S. ve Sarışık, M. (2013). Politik Krizlerin Turizm Talebi Üzerindeki Etkisine Yönelik Bir Araştırma "Mısır Turizmi, Akademik Turizm ve Yönetim Araştırmaları Dergisi, 1(1), 57-69.

Yeşiltaş, M., Seren, M. ve Özçelik, N. (2017). Fırat Kalkanı Harekatı: Harekâtın İcrası, İstikrarın Tesisi ve Alınan Dersler, Rapor. (24 Ağustos 2017), 25.12.2019 tarihinde https://setav.org/assets/uploads/2017/10/R 91_FKA.pdf adresinden erişildi.

Yıldız, Z. (2011). Turizm Sektörünün Gelişimi ve İstihdam Üzerindeki Etkisi, Süleyman Demirel Üniversitesi Vizyoner Dergisi, 3(5), 5471.

YSK (2018). Yüksek Seçim Kurulu, Seçim Takvimi, 25.12.2019 tarihinde http://www.ysk.gov.tr/doc/dosyalar/docs/2 4Haziran2018/2018CBMV-SecimTakvimi.pdf adresinden erişildi.

YSK (2019). "31 Mart 2019 Mahalli İdareler Genel Seçimleri, Seçim Takvimi" 25.12.2019 tarihinde http://www.ysk.gov.tr/tr/2019mahalli-i\%CC\%87dareler-secimtakvimi/77915 adresinden erişildi.

Zengin, B. (2010). Turizm Sektörünün Türkiye Ekonomisine Reel ve Moneter Etkileri, Akademik Incelemeler Dergisi, 5(1). 102-126. 